\title{
Distribution of PCDD/Fs and dioxin-like PCBs in sediment and plants from a contaminated salt marsh (Tejo estuary, Portugal)
}

\author{
Margarida Nunes • Anaïs Vernisseau • Philippe Marchand • Bruno Le Bizec • \\ Fernando Ramos $\cdot$ Miguel A. Pardal
}

Received: 7 August 2013 / Accepted: 16 September 2013 / Published online: 2 October 2013

(C) Springer-Verlag Berlin Heidelberg 2013

\begin{abstract}
Concentrations and profiles of 2,3,7,8-substituted polychlorinated dibenzo- $p$-dioxins, polychlorinated dibenzofurans $(\mathrm{PCDD} / \mathrm{Fs})$ and dioxin-like polychlorinated biphenyls (dlPCBs) were investigated in sediment and plants collected from a salt marsh in the Tejo estuary, Portugal. The highest PCDD/F and dl-PCB concentrations were detected in uncolonized sediments, averaging $325.25 \pm 57.55 \mathrm{pg} \mathrm{g}^{-1}$ dry weight $(\mathrm{dw})$ and $8,146.33 \pm 2,142.14 \mathrm{pg} \mathrm{g}^{-1} \mathrm{dw}$, respectively. The plants Sarcocornia perennis and Halimione portulacoides growing in PCDD/F and dl-PCB contaminated sediments accumulated contaminants in roots, stems, and leaves. It was observed that $\mathrm{PCDD} / \mathrm{F}$ and dl-PCB concentrations in roots were significantly lower in comparison with stems and leaves. In general, concentration of $\Sigma \mathrm{PCDD} / \mathrm{Fs}$ and $\Sigma \mathrm{dl}-\mathrm{PCBs}$ in $H$. portulacoides tissues were found to be twofold higher than those in S. perennis, indicating a difference in the accumulation capability of both species. Furthermore, congener profiles changed between sediments and plant tissues, reflecting a selective accumulation of low chlorinated PCDD/Fs and non-ortho dl-PCBs in plants.
\end{abstract}

Responsible editor: Ester Heath

Electronic supplementary material The online version of this article (doi:10.1007/s11356-013-2178-8) contains supplementary material, which is available to authorized users.

M. Nunes $(\bowtie) \cdot$ M. A. Pardal

CFE - Centre for Functional Ecology, Department of Life Sciences, University of Coimbra, Apartado 3046, 3001-401 Coimbra, Portugal e-mail:mnc@ci.uc.pt

M. Nunes · F. Ramos

$\mathrm{CEF}$ - Center for Pharmaceutical Studies, Health Sciences Campus, Bromatology Laboratory, Pharmacy Faculty, University of Coimbra, Azinhaga de Santa Comba, 3000-548 Coimbra, Portugal

A. Vernisseau • P. Marchand • B. Le Bizec

Oniris, Laboratoire d'Étude des Résidus et Contaminants

dans les Aliments (LABERCA), LUNAM Université, CS50707,

44307 Nantes, France
Keywords Persistent organic pollutants $\cdot \mathrm{PCDD} / \mathrm{Fs} \cdot \mathrm{PCBs}$. Sediment $\cdot$ Halophytes $\cdot$ Sarcocornia perennis $\cdot$ Halimione portulacoides $\cdot$ Estuary

\section{Introduction}

Assessment of dioxin-like compound contamination in estuarine systems continues to be of concern all over the world due to their deleterious effects on ecosystem functions and human health. Chemical contaminants such as polychlorinated dibenzo- $p$-dioxins and dibenzofurans (PCDD/Fs) and polychlorinated biphenyls (PCBs) have the propensity to bioaccumulate in biota and biomagnify in food webs. They are also known to cause adverse effects including carcinogenicity, reproductive impairment, and endocrine disruption in wildlife and humans (Van den Berg et al. 2006; Wenning et al. 2011). Salt marshes are areas of deposition for suspended particulate matter transported by tidal currents, and consequently act as sinks for sediment-bound contaminants (Barra et al. 2004; Hwang et al. 2006). Since salt marsh plants make significant contributions to the detrital estuarine food web (Masters and Inman 2000; Wall et al. 2001), the uptake of dioxin-like compounds accumulated in sediments may be responsible for a further transfer of pollutants into the food web.

Several studies have evaluated the ability of marsh vegetation to accumulate heavy metals (Castro et al. 2009), polycyclic aromatic hydrocarbons (Watts et al. 2006), organochlorine pesticides (Liu et al. 2006), and tributyltin (Carvalho et al. 2010). However, little information is available on PCDD/F and PCB contamination in salt marsh plants (Mrozek and Leidy 1981; Masters and Inman 2000). Moreover, plant uptake of PCDD/Fs and PCBs has been a controversial topic, with numerous authors considering that the hydrophobic 
nature of such compounds and the consequent strong adsorption on sediment particles rendered them less available for uptake by roots (Wu et al. 2002; Schuhmacher et al. 2006; Uegaki et al. 2006). On the contrary, other researchers state that the primary pathway of PCDD/F and PCB contamination in plants is uptake from roots and possible translocation to aboveground parts (Engwall and Hjelm 2000; Zeeb et al. 2006; Greenwood et al. 2011). Thus, the objectives of this work were (1) to determine the concentration of 2,3,7,8substituted PCDD/Fs and dl-PCBs in two plant species commonly found in temperate estuaries and associated sediments; (2) to compare the dioxin-like compound contents between plant species and between tissues (root, stems, and leaves); and (3) to explore the relationship between PCDD/F and dlPCB profiles of sediments and plant tissues.

\section{Material and methods}

Study site and sampling

Tejo estuary is the largest in the western European coast. It covers an area of about $320 \mathrm{~km}^{2}$ and is considered the most impacted estuarine system in Portugal, as a result of different anthropogenic pressures arising from heavy industrialization and urbanization. The estuary has extensive intertidal mudflats from which about $15 \%$ of the area is covered by salt marshes, where Sarcocornia perennis (Caryophyllalles, Chenopodiaceae) and Halimione portulacoides (Caryophyllalles, Chenopodiaceae) are two of the most representative halophyte species found (Caçador and Duarte 2012). This study was carried out in a salt marsh located at the mouth of a polluted tributary, the Trancão River $\left(38^{\circ} 79^{\prime} \mathrm{N} 9^{\circ} 09^{\prime} \mathrm{W}\right)$, that discharges directly into Tejo estuary (Fig. 1).

Samples were randomly collected over an area of $500 \mathrm{~m}^{2}$ in August 2011 during low tide. Five replicates of leaves, stems, and belowground tissues were taken from each species $(S$. perennis and $H$. portulacoides), together with rhizosediment samples (sediment surrounding plant roots and rhizomes). Since $S$. perennis does not have a true shoot system with leaves and stems, the swollen photosynthetic stems (referred to as leaves hereafter) were differentiated from the dry perennial shoots (referred to as stems hereafter). Aboveground material was harvested, and belowground material and rhizosediment were taken with a spade from the same place to a depth of $15 \mathrm{~cm}$, where most roots and rhizome are present. Five composite sediment samples from the lower uncolonized intertidal area were also collected. Each sample consisted of sediment from 0 to $15-\mathrm{cm}$ depth taken in three random points within $1 \mathrm{~m}^{2}$. All samples were stored in aluminium foil and transported to the laboratory where they were kept in a fridge at $4{ }^{\circ} \mathrm{C}$.
Sample preparation

Belowground plant parts were carefully separated from sediment under a flux of water using a $500 \mu \mathrm{m}$ mesh size. Roots, stems, and leaves were carefully rinsed with ultra-pure Milli$\mathrm{Q}$ water to remove any adhering particles and avoid cross contamination. Prior to $\mathrm{PCDD} / \mathrm{F}$ and dl-PCB analysis, plant tissues were oven-dried at $60{ }^{\circ} \mathrm{C}$ until a constant weight was reached. The dry sample was then ground to a power using a grinding mill.

Similarly, sediment samples were oven-dried, cleaned of roots and debris, homogenized, and ground to a powder using a pestle and mortar. Sediment samples were also analyzed for total organic carbon (TOC) and fine fraction $(<63 \mu \mathrm{m})$ content. TOC was determined using a Carlo Erba CHN analyzer, and grain size analysis was performed according to the classification method of Brown and McLachland (1990).

\section{$\mathrm{PCDD} / \mathrm{F}$ and $\mathrm{PCB}$ analysis}

The $17 \mathrm{PCDD} / \mathrm{F}$ congeners with chlorine substitution in the 2 , 3,7 , and 8 positions and the $12 \mathrm{PCBs}$ with dioxin-like activity (non-ortho PCBs 77, 81, 126, and 169 and mono-ortho PCBs $105,114,118,123,156,157,167$, and 189) were considered for this purpose.

The analysis was performed as described by Costera et al. (2006). Samples were extracted in an accelerated solvent extraction device (ASE 300, Dionex, Sunnyvale, CA, USA) at a temperature of $120{ }^{\circ} \mathrm{C}$ and pressure of 100 bar, using as solvent a mixture composed of toluene and acetone at 70:30 (v/v). The resultant extracts were purified and fractionated in three successive chromatographic steps involving multilayered silica gel, Florisil, and carbon columns. Analysis of clean extracts was conducted using a Hewlett-Packard 6890 gas chromatograph (Palo Alto, CA, USA) equipped with a high-resolution mass spectrometer. All target compounds were quantified using the isotope dilution method.

Samples were analyzed according to a validated and accredited method (ISO 17025:2005 standard). The procedure integrated the quality assurance and quality control criteria to fulfill the requirements of the European legislation laying down sampling procedures and the analysis methods for determination of PCDD/Fs and dl-PCBs (EC 2006). To ensure quality of our data, blanks were included in every series of samples to check for interference and cross-contamination. The limits of detection ranged from 0.003 to $0.010 \mathrm{pg} \mathrm{g}^{-1}$ of dry weight (dw) for PCDD/Fs and from 0.009 to $0.062 \mathrm{pg} \mathrm{g}^{-1}$ $\mathrm{dw}$ for dl-PCBs. To check on the accuracy of the analytical method, recovery tests were also carried out. The recoveries of individual congeners varied from 30 to $140 \%$ as required by the EC regulation 1883/2006. 
Fig. 1 Tejo estuary and location of the sampling area

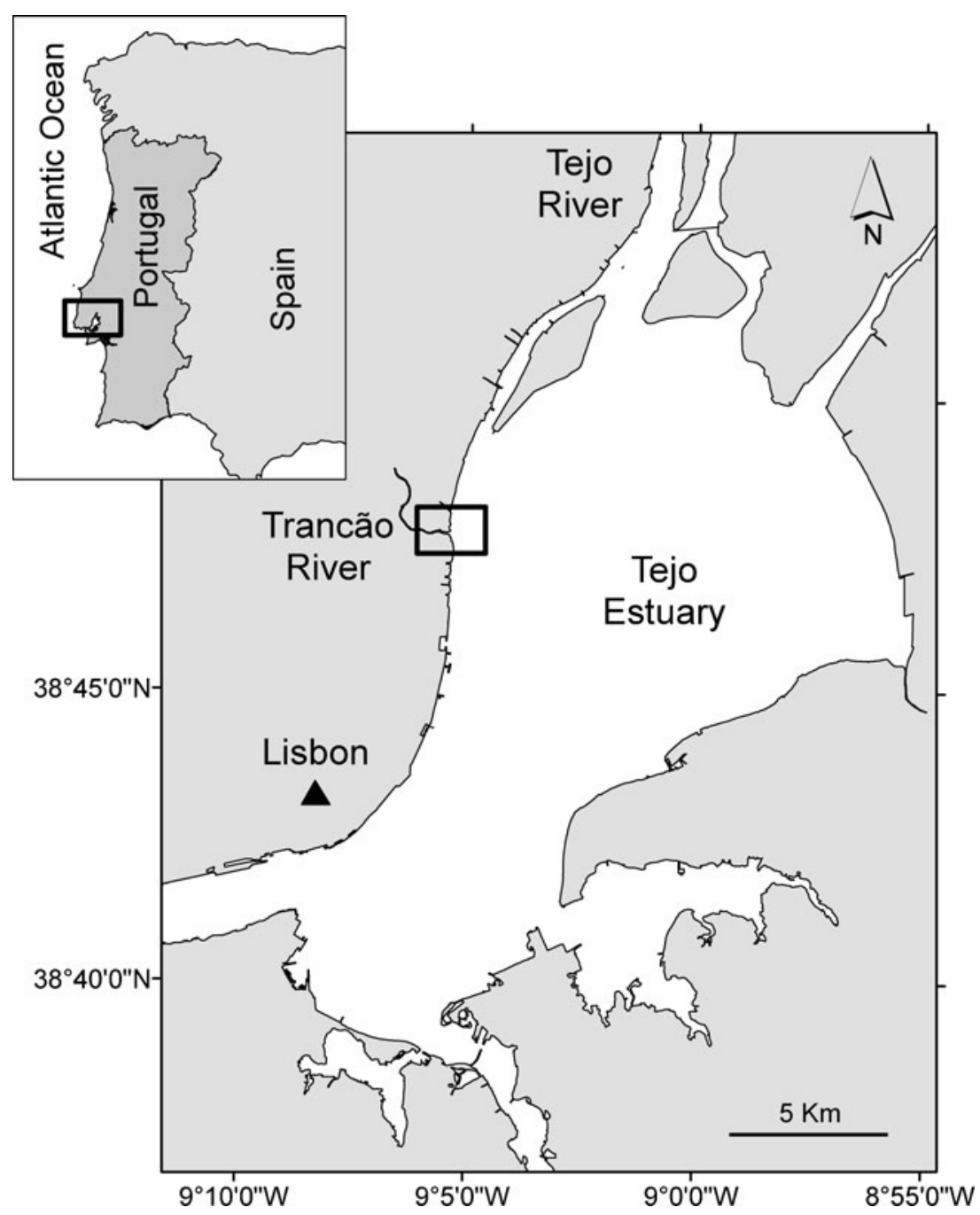

Data analysis

The relationship between $\mathrm{PCDD} / \mathrm{F}$ and $\mathrm{dl}-\mathrm{PCB}$ concentrations and physical characteristics of sediment (TOC and fine fraction content) were tested using Pearson's correlation. Analysis of variance (one-way ANOVA) was performed to determine differences in sediment characteristics between colonized and uncolonized sediments, and to evaluate differences in PCDD/F and dl-PCB concentrations between sediments, and between tissues of the same plant species. Student's $t$ test was used to compare PCDD/F and dl-PCB concentrations between similar tissues of $S$. perennis and $H$. portulacoides. All statistical tests were performed using the software Statistica 8.0 (StatSoft Inc., USA). Principal component analysis (PCA) was used to further explore differences in the $\mathrm{PCDD} / \mathrm{F}$ and $\mathrm{PCB}$ congener profiles between sediments and tissues of both plant species. Multivariate analysis was carried out using the software package CANOCO 4.5 (Microcomputer Power, USA).

\section{Results and discussion}

$\mathrm{PCDD} / \mathrm{F}$ and dl-PCB concentrations in sediments

The highest PCDD/F and dl-PCB concentrations were detected in uncolonized sediments, averaging $325.25 \pm 57.55 \mathrm{pg} \mathrm{g}^{-1} \mathrm{dw}$ and $8,146.33 \pm 2,142.14 \mathrm{pg} \mathrm{g}^{-1} \mathrm{dw}$, respectively (given in Supplementary material). S. perennis rhizosediments were found to have a total PCDD/F concentration ( $\Sigma$ PCDD/F) of $293.09 \pm 39.03 \mathrm{pg} \mathrm{g}^{-1} \mathrm{dw}$ and those of $H$. portulacoides had $294.89 \pm 75.88 \mathrm{pg} \mathrm{g}^{-1} \mathrm{dw}$. Whereas, the total dl-PCB concentration ( $\Sigma$ dl-PCB) was $6,404.64 \pm 3,781.60 \mathrm{pg} \mathrm{g}^{-1} \mathrm{dw}$ in $S$. perennis rhizosediments and 5,874.17 $\pm 3,255.10 \mathrm{pg} \mathrm{g}^{-1} \mathrm{dw}$ in those of $H$. portulacoides. $\Sigma$ PCDD/F and $\Sigma$ dl-PCB concentrations found in rhizosediments were lower than those from uncolonized sediment. These lower levels of dioxin-like compounds may be a result of the presence of salt marsh plants. However, the difference of $\Sigma \mathrm{PCDD} / \mathrm{F}$ and $\Sigma \mathrm{dl}-\mathrm{PCB}$ concentrations between colonized and uncolonized sediments was not statistically significant. Nevertheless, this result suggests that 
salt marsh plants may play some role in reducing dioxin-like compound concentration from contaminated sediments. Highly hydrophobic contaminants (octanol-water partition coefficient $>6$ ) bind strongly to sediment particles and, therefore, are not expected to be susceptible to plant uptake (Wu et al. 2002). However, a few studies reported uptake of PCDD/Fs and dlPCBs by plants, considering that root exudates may be involved in a mechanism of solubilization of hydrophobic compounds, and consequently in enhanced desorption from soil and increased root uptake (Campanella and Paul 2000). Moreover, even when compounds are poorly taken up by plants, roots can interact with the surrounding sediment by different processes, stimulating the microbial activity in the rhizosphere and increasing compound degradation and/or removal. For example, plant exudates contain molecules that can be used by microorganisms as substrate or as factors inducing dehalogenation of chlorinated compounds (Chaudhry et al. 2005). Plants can also secrete enzymes into the rhizosphere that can initiate transformation of organic compounds and facilitate further microbial metabolism (Alkorta and Garbisu 2001). Furthermore, plants increase oxygen diffusion in the rhizosphere, which potentially enhances microbial oxidative transformation (Chaudhry et al. 2005).

Sediments were constituted mainly by silt and clay $(<63 \mu \mathrm{m})$, independently of the presence of plants. Nevertheless, uncolonized sediment had lower fined-grain content compared with rhizosediments (given in Supplementary material). TOC content ranged from $3.0 \pm 0.28$ to $3.7 \pm 0.42 \%$. Sediments between roots of $S$. perennis and $H$. portulacoides contained higher percentage of fine particles $\left(F_{2,12}=13.334\right.$, $p<0.001)$ and TOC than uncolonized sediments $\left(F_{2,12}=4.158\right.$, $p<0.05$ ). Since fine particles exhibit a large surface area available for adsorption of organic carbon, it is not surprising that a significant correlation $(r=0.869, p<0.001)$ was found between fine fraction and TOC content in the analyzed sediments. However, no significant correlation between the referred sediment characteristics and dioxin-like contaminants was observed in the present study. It can be assumed, hence, that some factors other than fine particles and TOC content may affect the distribution of PCDD/Fs and dl-PCBs in sediments.

\section{PCDD/F and dl-PCB distribution in plant tissues}

All target analytes were detected in the analyzed plant tissues (given in Supplementary material). $\Sigma \mathrm{PCDD} / \mathrm{F}$ concentrations in $S$. perennis varied from $17.29 \pm 1.59 \mathrm{pg} \mathrm{g}^{-1} \mathrm{dw}$ in roots to $1.72 \pm 0.13 \mathrm{pg} \mathrm{g}^{-1} \mathrm{dw}$ in leaves, and in H. portulacoides ranged between $30.87 \pm 11.93$ and $2.28 \pm 0.54 \mathrm{pg} \mathrm{g}^{-1} \mathrm{dw}$, in roots and in leaves, respectively (Fig. 2a). $\Sigma$ dl-PCB concentrations in $S$. perennis varied between $971.62 \pm 139.60 \mathrm{pg} \mathrm{g}^{-1} \mathrm{dw}$ in roots and $159.07 \pm 45.70 \mathrm{pg} \mathrm{g}^{-1} \mathrm{dw}$ in stems; whereas in $H$. portulacoides, it ranged from $2,253.70 \pm 822.24 \mathrm{pg} \mathrm{g}^{-1} \mathrm{dw}$ in roots to $247.67 \pm 54.25 \mathrm{pg} \mathrm{g}^{-1} \mathrm{dw}$ in stems (Fig. 2b). Due to the strong adsorption of $\mathrm{PCDD} / \mathrm{Fs}$ and $\mathrm{PCBs}$ to fine-grained sediments rich in organic matter, a low bioavailability and subsequent low uptake by roots was expected for these highly hydrophobic compounds (Liu and Schnoor 2008). As a matter of fact, $S$. perennis root tissue showed only $6 \%$ of $\Sigma \mathrm{PCDD} / \mathrm{F}$ concentration of the corresponding rhizosediment, and $15 \%$ of $\Sigma$ dl-PCBs. The $\Sigma$ PCDD/F concentration on $H$. portulacoides roots was found to be $11 \%$ of the respective rhizosediment, while $\Sigma$ dl-PCB concentration was $38 \%$. Moreover, the results indicate a minor root accumulation of $\mathrm{PCDD} / \mathrm{Fs}$ compared to dl-PCBs.

A similar partition of PCDD/F and PCB content was observed in S. perennis and H. portulacoides (Fig. 2a, b). PCDD/ $\mathrm{F}$ concentrations in tissues showed a declining gradient from roots $>>$ stems $>$ leaves, while dl-PCB values decreased in the order roots $>>$ leaves $>$ stems. In addition, both species accumulated statistically significant lower $\left(F_{2,12}=325.21, p<0.001\right.$ for PCDD/Fs in $S$. perennis; $F_{2,12}=139.83, p<0.001$ for PCBs in $S$. perennis; $F_{2,12}=89.66, p<0.001$ for $\mathrm{PCDD} / \mathrm{Fs}$ in $H$. portulacoides; and $F_{2,12}=108.23, p<0.001$ for PCBs in $H$. portulacoides) concentrations in the aboveground tissues in comparison with roots, suggesting that $\mathrm{PCDD} / \mathrm{Fs}$ and dlPCBs are not transported inside $S$. perennis and $H$. portulacoides extensively. Dioxin-like compounds with a log octanol-water partition coefficient $\left(\log \mathrm{K}_{\mathrm{OW}}\right)$ higher than 5 have been reported to be insignificantly translocated within plants (Hülster and Marschner 1993; Liu and Schnoor 2008), with the exception of the species Cucurbita pepo (Zeeb et al. 2006; Greenwood et al. 2011).

The interpretation of $\mathrm{PCDD} / \mathrm{F}$ and dl-PCB concentrations in stems and leaves is difficult since accumulation of contaminants in aboveground tissues may be attributed to a combination of translocation after root uptake, foliar uptake from air, or by direct contact between sediment particles and plant surfaces (Smith and Jones 2000). Moreover, possible losses/ transformation of compounds due to metabolism within plants cannot be excluded (Wild et al. 2005; Liu et al. 2009).

Previous studies showed that there is a remarkable diversity in uptake and translocation of organic contaminants, dependent not only on the specific properties of each compound but also on the characteristics of the plant species (Liu and Schnoor 2008; Matsuo et al. 2011). In the present study, the two species showed statistically significant differences $(p<$ 0.05 ) in concentrations of dioxin-like compounds in analogous tissues (the only exception occurred for $\mathrm{PCDD} / \mathrm{Fs}$ in leaves). $\Sigma \mathrm{PCDD} / \mathrm{F}$ and $\Sigma \mathrm{dl}-\mathrm{PCB}$ concentrations in $H$. portulacoides tissues was found to be roughly twice as much as that in $S$. perennis, with exception of $\mathrm{PCDD} / \mathrm{Fs}$ in leaves where values are only slightly higher in $H$. portulacoides (Fig. 2a, b). The different concentration levels found in belowground tissues may be caused by distinct type or amount of organic exudates from the roots of the studied species (Ryan et al. 2001). Also, Dettenmaier et al. (2009) suggested 
Fig. 2 Concentration of a total PCDD/Fs and $\mathbf{b}$ total dl-PCBs in roots, stems, and leaves of two plant species (S. perennis and $H$. portulacoides) collected from the Tejo estuary ( $\left.\operatorname{~gg~g~}^{-1} \mathrm{dw}\right)$. Results are expressed as the mean + standard deviation $(n=5)$. Different symbols above bars indicate statistically significant differences between tissues of the same species $(p<0.05)$ a

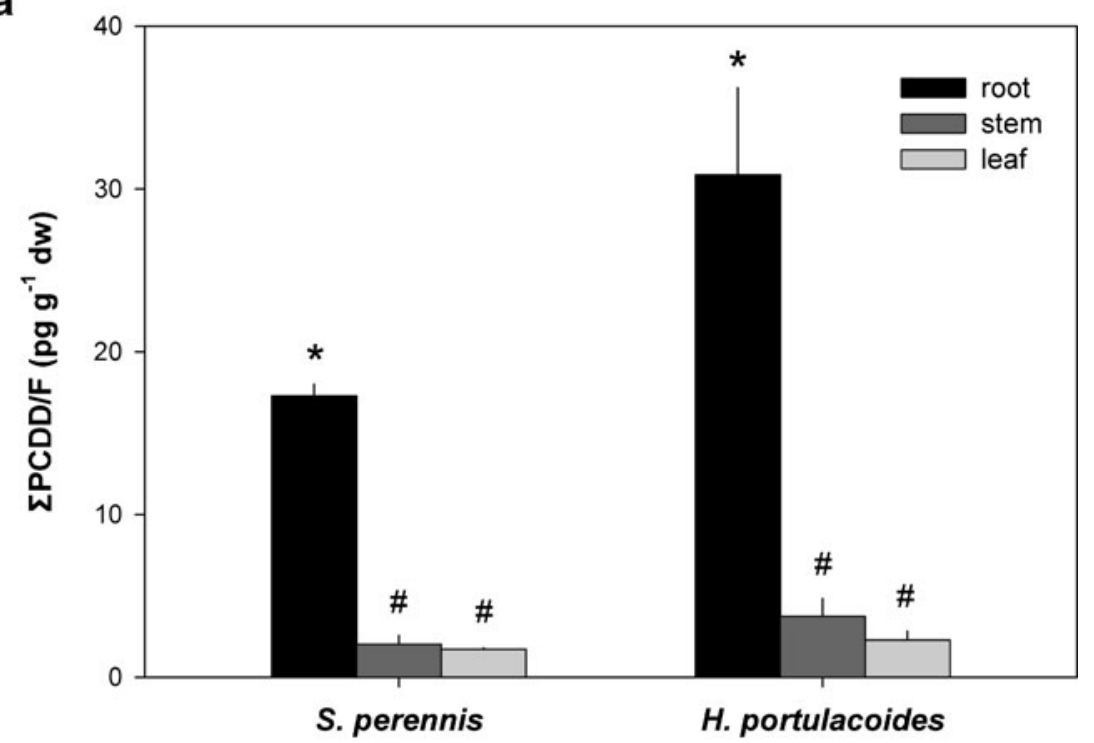

b

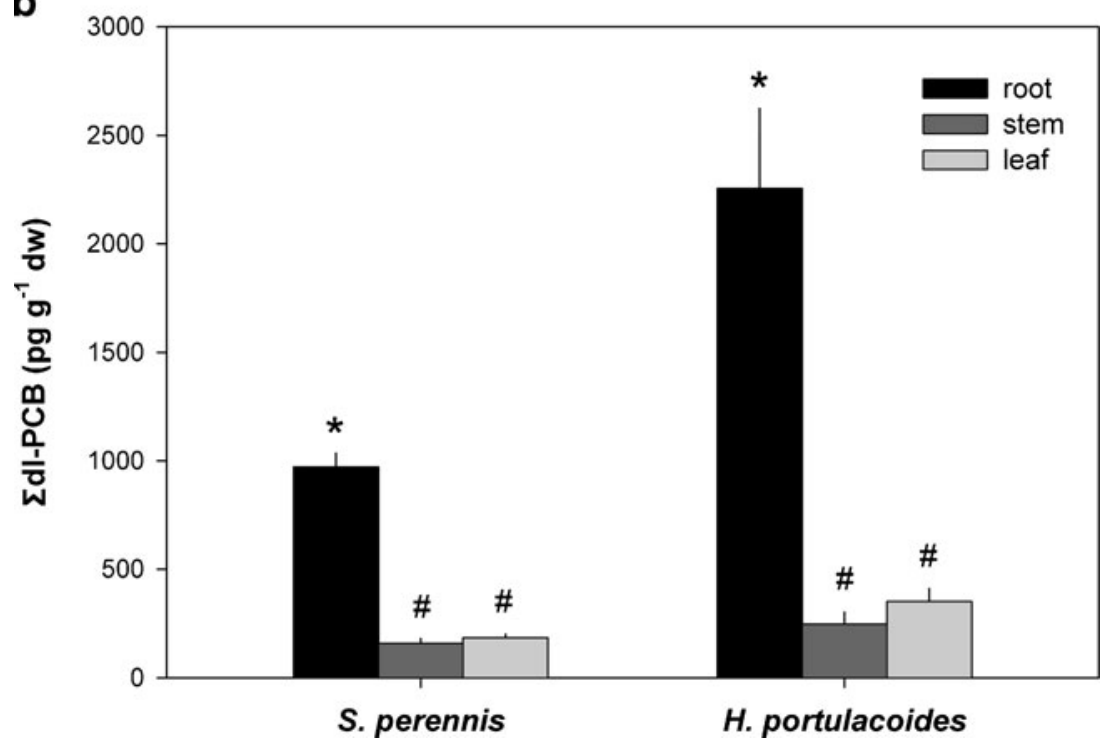

that differences in root lipid contents might influence plants uptake of hydrophobic compounds from sediment, since these chemicals can be predicted to adsorb to lipids present in root endodermis and not actually taken up. Similarly, lipid composition and foliage area can be species-specific properties that influence accumulation of pollutants in leaves.

\section{Root concentration factors}

To compare the ability of $S$. perennis and $H$. portulacoides roots to accumulate dioxin-like compounds, the root concentration factor $(\mathrm{RCF})$, defined as the ratio between concentration of a given chemical in roots and in the surrounding medium, was calculated (Fig. 3). RCFs in $S$. perennis were significantly lower $(p<0.05)$ than in $H$. portulacoides for most of the $\mathrm{PCDD} / \mathrm{F}$ homologues (except HpCDD, OCDD, and TCDF) and dl-PCB congeners (except mono-ortho PCBs 104, 115, and 123). These results indicate that there is a difference in accumulation capability between the two plant species.

The $\log \mathrm{K}_{\mathrm{OW}}$ is used to predict and model the migration of hydrophobic organic compounds in water and sediment/soil. For PCDD/F and PCB congeners, $\log \mathrm{K}_{\mathrm{OW}}$ rises with increasing chlorine content (Chen et al. 2001; Yeh and Hong 2002). This means that higher chlorinated forms are less soluble and in consequence are expected to be less bioavailable to plants (Zeeb et al. 2006). In the present study, both plant species showed lower RCFs for PCDD/Fs than for dl-PCBs with corresponding number of chlorine substitutions (Fig. 3). The superior $\log \mathrm{K}_{\mathrm{OW}}$ of PCDD/Fs in comparison with the coefficient of dl-PCBs with identical chlorine content might explain why dl-PCBs seem to be more susceptible to accumulate in roots than $\mathrm{PCDD} / \mathrm{Fs}$. 


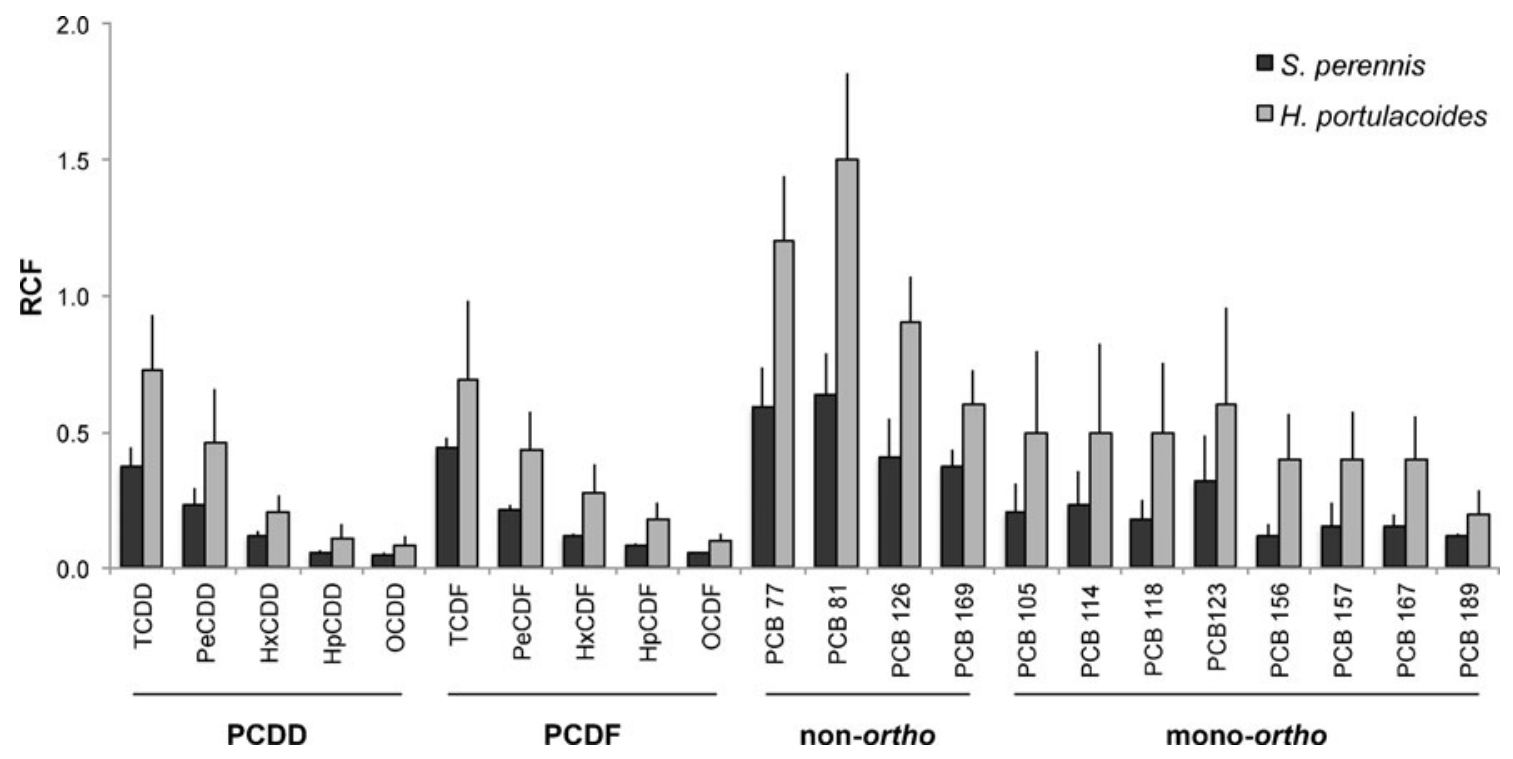

Fig. 3 Root concentration factors $(R C F S)$ for PCDD/F homologues and dl-PCB congeners in S. perennis and H. portulacoides roots. Results are expressed as the mean + standard deviation $(n=5)$

In addition, a reduction of RCFs with increase in chlorine substitutions in $\mathrm{PCDD} / \mathrm{F}$ was observed for both plants (Fig. 3). The significant negative correlation $(r=-0.639$, $p<0.05$ for $S$. perennis; $r=-0.738, p<0.001$ for $H$. portulacoides) found between RCFs and $\log \mathrm{K}_{\mathrm{OW}}$ confirms that $\mathrm{PCDD} / \mathrm{F}$ accumulation by roots can be influenced by the number of chlorines atoms in the molecules and, thus, by their solubility (Satchivi et al. 2001). Inui et al. (2008) also observed this decrease in accumulation of PCDD/Fs with increasing hydrophobicity.

In contrast, dl-PCB accumulation in both studied plants seems to be affected not only by chlorine content, and hence $\log \mathrm{K}_{\mathrm{OW}}$ and molecular weight, but also by the presence of chlorine atoms in ortho-positions; congeners with no substitution in the ortho-positions had higher RCFs in comparison with mono-ortho congeners with an identical number of chlorines (Fig. 3). In agreement, RCFs for dl-PCB congeners were not significantly correlated with $\log \mathrm{K}_{\mathrm{OW}}$. Structure-selective accumulation was documented before for dioxin-like compounds (Inui et al. 2008; Matsuo et al. 2011) in some particular zucchini cultivars. However, contrary to our findings, they reported bioconcentration factors for mono-ortho-chlorinated biphenyls several times as high as those for PCBs without chlorine at the ortho-positions. Since only ortho-substituted congeners may be polar molecules with the ability to form hydrogen bonds and, thus, show higher solubility in water (IPCS 2003), the results found in the present study are contrary to our expectations.

PCDD/F and dl-PCB profiles in sediment and plant tissues

Both sediment and plant tissues presented PCDD/F profiles with greater contributions of higher chlorinated homologues, namely octa-CDD/F and hepta-CDF (Fig. 4a). However, plant tissues showed greater percentages of tetra-, penta-, and hexa$\mathrm{CDD} / \mathrm{F}$ than sediments. Regarding dl-PCB congener contributions, PCB 118 and 105 were the most abundant in all analyzed samples (Fig. 4b). Further, non-ortho PCBs (congeners 77, 81, 126 , and 169) had higher contributions in tissues of $S$. perennis and $H$. portulacoides in comparison with the surrounding sediments, again suggesting the existence of selective accumulation of dl-PCBs with no chlorine at the ortho-positions in plants.

PCA results confirmed the distinct PCDD/F and dl-PCB profiles of sediments and plant tissues (Fig. 5). For PCDD/Fs, the first principal component (PC1) explained $98.2 \%$ of data variability. $\mathrm{PC} 1$ showed that sediment samples are clearly associated with higher contributions of octa-CDD/F, hepta$\mathrm{CDF}$, and hexa-CDF homologue groups, whereas plant tissues are mostly related with less chlorinated PCDD/Fs (Fig. 5a). These differences may reflect an easier adsorption/absorption of congeners with a low degree of chlorination, due to their lower $\log \mathrm{K}_{\mathrm{OW}}$, higher solubility, and smaller molecular weight (Zeeb et al. 2006; Inui et al. 2008). Although $S$. perennis and $H$. portulacoides showed significantly different $\mathrm{PCDD} / \mathrm{F}$ concentrations (Fig. 3a), according to the PCA, no distinction was found between their tissue profiles (Fig. 5a). The second principal component (PC2) described a very small fraction of total variance $(0.9 \%)$, and allowed a slight separation of root samples from stems and leaves, independently of the plant species (Fig. 5a). The profile found in roots illustrates the transition between sediments and aboveground plant tissues. The structure of root epidermis, particularly the thickness of waxes on its surface, determines the root capacity for adsorbing PCDD/Fs and consequently the diffusion into the root core and vascular tissues (Müller et al. 1994; Meneses et al. 2002). Thus, the lipid 

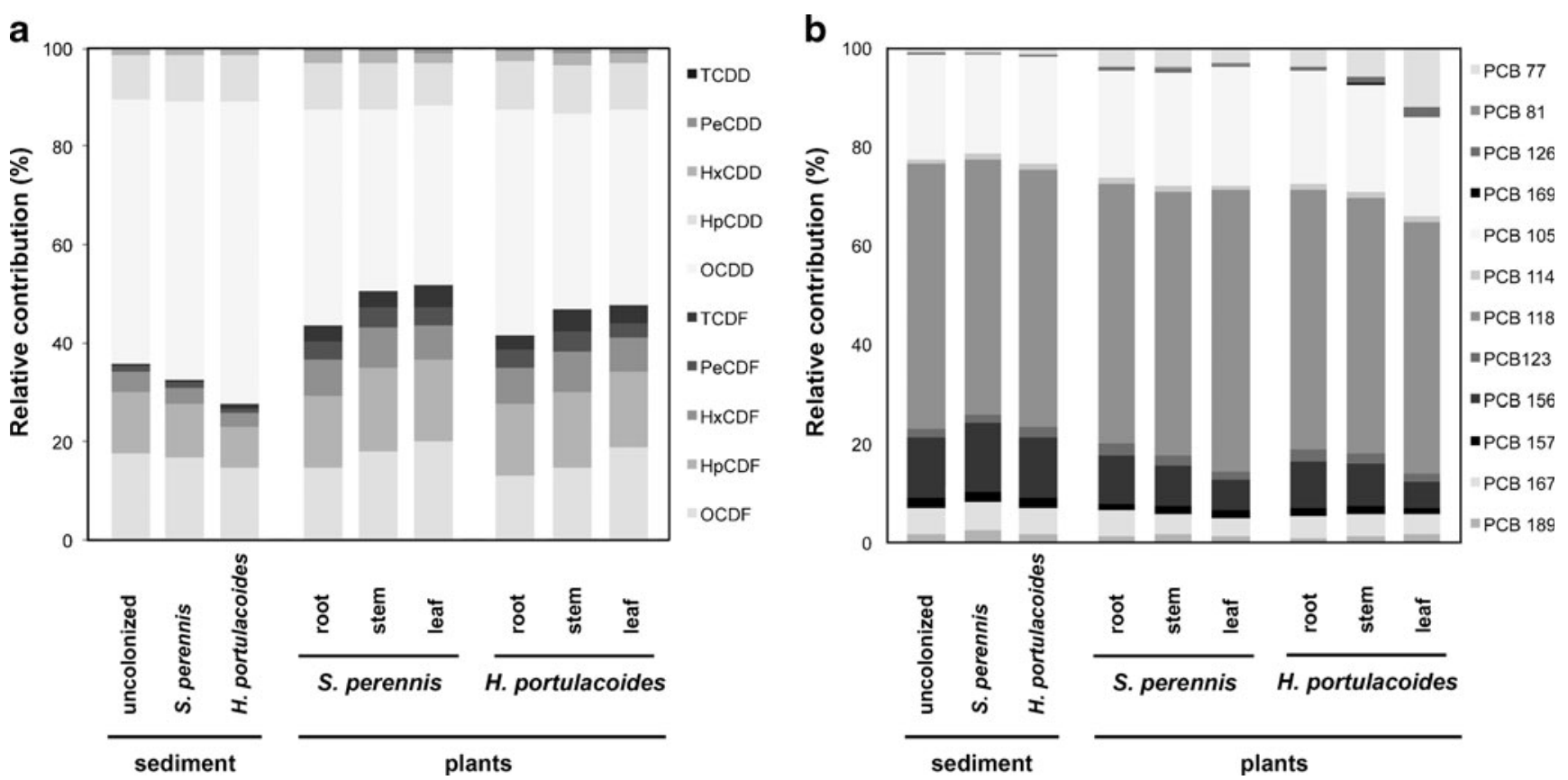

Fig. 4 Mean relative contribution of a PCDD/F homologues and $\mathbf{b}$ dl-PCB congeners in sediments and tissues of salt marsh plants $S$. perennis and $H$. portulacoides collected from the Tejo estuary $(n=5)$

nature of root epidermis may result in higher chlorinated congeners adsorbed to root surface, while less chlorinated PCDD/ Fs are preferentially taken up. Sediment samples also showed a gradient along PC2 (Fig. 5a). This profile variation demonstrates that the presence of salt marsh plants may in fact influence the PCDD/F content of sediments.

As for dl-PCBs, the PCA showed that the profiles of all three sediment types were similar, but differed considerably in comparison with plant samples (Fig. 5b). The two principal components accounted for $90.8 \%$ of total variance $(84.0 \%$ for PC1 and $6.8 \%$ for $\mathrm{PC} 2$ ). According to $\mathrm{PC} 1$, sediment samples showed higher contributions of mono-ortho PCBs, while plant tissues were mainly associated with non-ortho PCBs. Thus, the absence of chlorine atoms in the ortho-positions seems to facilitate the accumulation of dl-PCB congeners in plant tissues, despite their lower water solubility. Similarly to PCDD/Fs, root samples revealed an intermediary dl-PCB profile. In addition, PC2 highlighted the dissimilarities between aboveground tissues of $S$. perennis and $H$. portulacoides; all samples are associated with non-ortho dl-PCBs, but $H$. portulacoides tissues, and especially their leaves, displayed a higher contribution of $\mathrm{PCB}$ 77 and PCB 126. Contrary to the observed for PCDD/Fs, the two plant species not only accumulated different dl-PCB concentrations (Fig. 3b), but also showed distinct dl-PCB profiles (Fig. 5b).

As mentioned before, contamination of aboveground vegetation by dioxin-like compounds may occur from sediment through a variety of mechanisms as follows: root uptake and consequent translocation, volatilization from the sediment surface following by adsorption onto the plant surface, contamination of the plant's foliage by direct contact with sediment particles, and direct deposition from atmosphere (Trapp and Matthies 1997; Wagrowski and Hites 1998; Smith and Jones 2000). Although volatilization followed by plant adsorption may be a major PCDD/F and PCB pathway in greenhouses, in the field, this mechanism is thought to be of minor importance (Trapp and Matthies 1997). Furthermore, considering that in the study area both species are exposed to similar conditions, the direct contact between vegetation and sediment particles would have resulted in similar PCDD/F and dl-PCB profiles in the aboveground parts of $S$. perennis and $H$. portulacoides. However, different profiles were found between the two species, indicating that sediment deposition is not the main pathway of foliage contamination. Plants may also be impacted by atmospheric contamination from sources such as municipal and hospital waste incineration plants (Wagrowski and Hites 1998; Schuhmacher et al. 2000). Yet, according to Coutinho et al. (2007), PCDD/F concentrations measured in ambient air from Lisbon region are comparable to those found in low contaminated urban areas. Moreover, similar areas located in the Tejo estuary showed inferior dioxin-like concentrations in sediment (Nunes et al, Occurrence of PCDD/ Fs and dioxin-like PCBs in superficial sediment of Portuguese estuaries, Submitted). Thus, atmospheric inputs of dioxin-like compounds in the studied salt marsh are assumed to be insignificant compared to the inputs from the Trancão River. Therefore, in this study, root uptake and transportation within plants appears to be a primary mechanism of $\mathrm{PCDD} / \mathrm{F}$ and dl-PCB contamination of aboveground tissues, although only very small amounts can reach stems and leaves. 
Fig. 5 Principal component analysis $(P C A)$ biplots of a $\mathrm{PCDD} / \mathrm{F}$ homologue and b dl-PCB congeners in tissues of salt marsh plants $S$. perennis and $H$. portulacoides and surrounding sediments collected from the Tejo estuary a

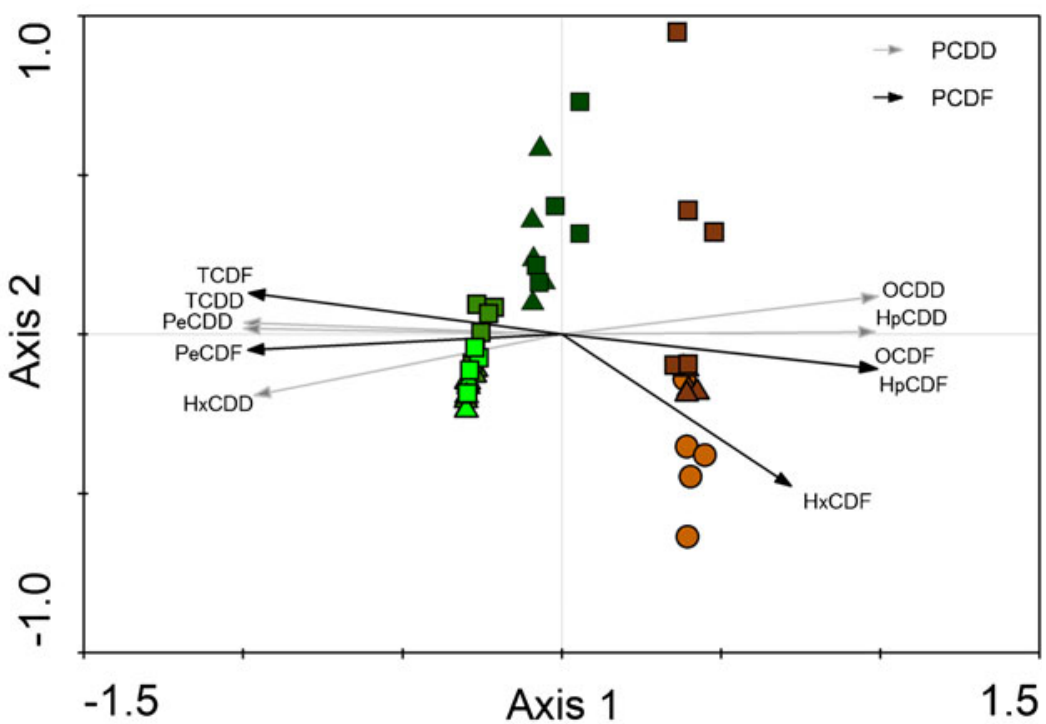

b

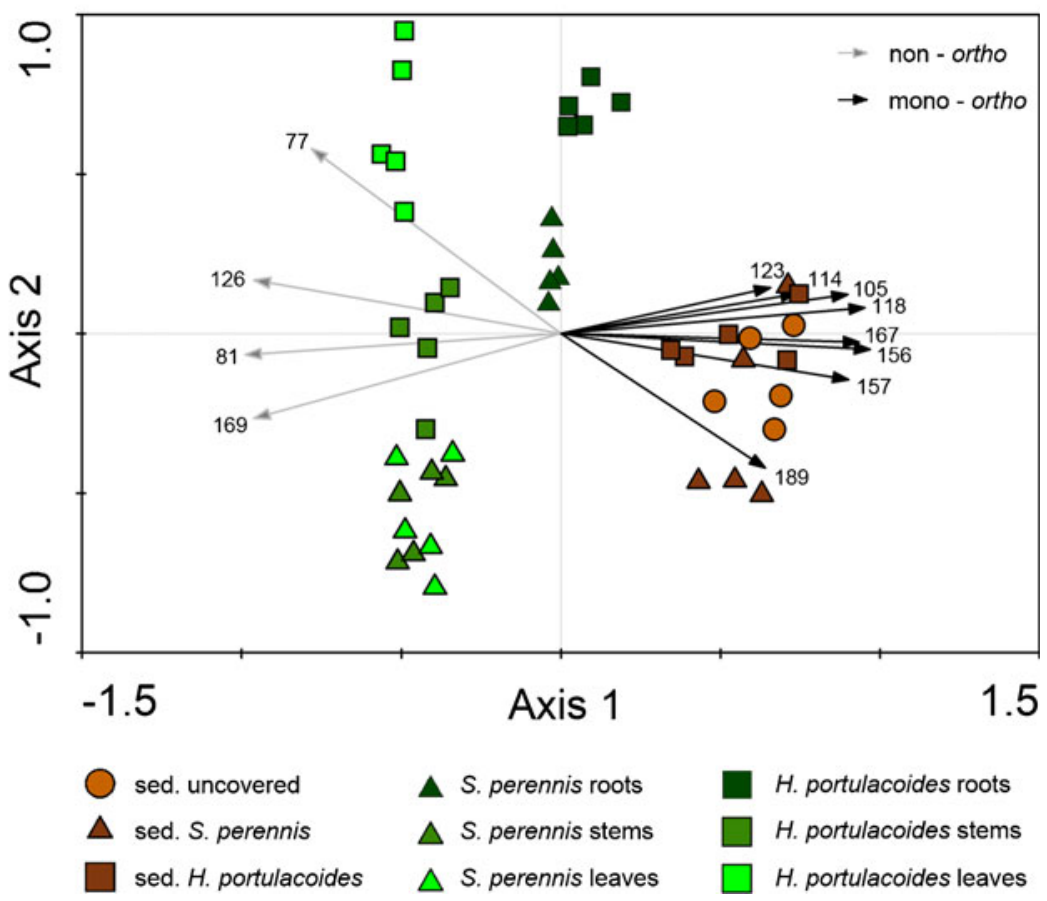

\section{Conclusions}

The presence of plants was associated with lower levels of dioxin-like compounds in salt marsh sediments. Furthermore, differences in homologue profiles of uncolonized sediment and rhizosediment samples suggest that vegetation may influence their PCDD/F composition.

Both plant species accumulated significantly lower concentrations in the aboveground tissues in comparison with roots, suggesting that despite the contaminant transfer occurred from sediments to the roots, they are not translocated in $S$. perennis and $H$. portulacoides extensively. For instance, $\mathrm{PCDD} / \mathrm{F}$ levels in rhizosediments are one to two orders of magnitude higher than concentrations in roots and aboveground tissues, respectively. Nevertheless, root uptake and transportation within plants might be a main mechanism of PCDD/F and dl-PCB contamination of aboveground vegetation in the study area, although involving reduced amounts of compounds.

This work also revealed that $S$. perennis accumulated minor quantities of dioxin-like compounds in comparison with $H$. portulacoides, meaning that one species may have a higher contribution in PCDD/F and PCB transfer from sediment to the trophic web. PCDD/F concentrations varied between $S$. perennis and $H$. portulacoides, but their homologue 
compositions were similar, suggesting that the mechanisms controlling the distribution of PCDD/Fs were similar in the two species. On the other hand, $S$. perennis and $H$. portulacoides not only accumulated different dl-PCB concentrations, but also showed distinct dl-PCB profiles. These results reveal that accumulation capability and eventual metabolism mechanisms of salt marsh plants vary, depending on the specific properties of each compound and on the characteristics of the plant species. Moreover, congener profiles shifted between sediments and plant, reflecting a selective accumulation of low chlorinated PCDD/Fs and non-ortho PCBs in plants.

Acknowledgments The authors would like to express their gratitude to Xavier Marques for the valuable help in the field campaign. The manuscript was greatly improved by the comments of three anonymous reviewers and the handling editor. This work was financially supported by the FCT - Fundação para a Ciência e Tecnologia, through a PhD grant attributed to MN Cardoso (SFRH/BD/46969/2008) co-funded by the $\mathrm{POPH} / \mathrm{FSE}$.

\section{References}

Alkorta I, Garbisu C (2001) Phytoremediation of organic contaminants in soils. Bioresour Technol 79:273-276

Barra R, Cisternas M, Suarez C, Araneda A, Pinones O, Popp P (2004) $\mathrm{PCBs}$ and $\mathrm{HCHs}$ in a salt-marsh sediment record from SouthCentral Chile: use of tsunami signatures and ${ }^{137} \mathrm{Cs}$ fallout as temporal markers. Chemosphere 55:965-972

Brown AC, McLachland A (1990) Ecology of sandy shores. Elsevier, Amsterdam, $328 \mathrm{pp}$

Caçador I, Duarte B (2012) Tagus Estuary salt marshes structure and dynamics: a historical perspective. In: Jordan SJ (ed) Estuaries: Classification and human impacts. Nova Science Publishers Inc, NY, pp 41-56

Campanella B, Paul R (2000) Presence, in the rhizosphere and leaf extracts of Zucchini (Cucurbita pepo L.) and Melon (Cucumis melo L.), of molecules capable of increasing the apparent aqueous solubility of hydrophobic pollutants. Int J Phytoremediation 2:145-158

Carvalho PN, Basto MCP, Silva MFGM, Machado A, Bordalo A, Vasconcelos MTSD (2010) Ability of salt marsh plants for TBT remediation in sediments. Environ Sci Pollut Res 17:1279-1286

Castro R, Pereira S, Lima A, Corticeiro S, Válega M, Pereira E, Duarte A, Figueira E (2009) Accumulation, distribution, and cellular partitioning of mercury in several halophytes of a contaminated salt marsh. Chemosphere 76:1348-1355

Chaudhry Q, Blom-Zandstra M, Gupta S, Joner EJ (2005) Utilising the synergy between plants and rhizosphere microorganisms to enhance breakdown of organic pollutants in the environment. Environ Sci Pollut R 12:34-48

Chen J, Quan X, Yazhi Z, Yan Y, Yang F (2001) Quantitative structureproperty relationship studies on n-octanol/water partitioning coefficients of PCDD/Fs. Chemosphere 44:1369-1374

Costera A, Feidt C, Marchand P, Le Bizec B, Rychen G (2006) PCDD/F and PCB transfer to milk in goats exposed to a long-term intake of contaminated hay. Chemosphere 64:650-657

Coutinho M, Pereira M, Borrego C (2007) Monitoring of ambient air PCDD/F levels in Portugal. Chemosphere 67:1715-1721

Dettenmaier EM, Doucette WJ, Bugbee B (2009) Chemical hydrophobicity and uptake by plant roots. Environ Sci Technol 43: 324-329
EC (2006) Commission Regulation (EC) No. 1883/2006 of 19 December 2006 laying down methods of sampling and analysis for the official control of levels of dioxins and dioxin-like PCBs in certain foodstuffs. Off J Eur Union L364:332-343

Engwall M, Hjelm K (2000) Uptake of dioxin-like compounds from sewage sludge into various plant species - assessment of levels using a sensitive bioassay. Chemosphere 40:1189-1195

Greenwood S, Rutter A, Zeeb BA (2011) The absorption and translocation of polychlorinated biphenyl congeners by Cucurbita pepo ssp pepo. Environ Sci Technol 45:6511-6516

Hülster A, Marschner H (1993) Transfer of PCDD/PCDF from contaminated soils to food and fodder crop plants. Chemosphere 27:439446

Hwang HM, Green PG, Young TM (2006) Tidal salt marsh sediment in California, USA. Part 1: occurrence and sources of organic contaminants. Chemosphere 64:1383-1392

Inui H, Wakai T, Gion K, Kim Y-S, Eun H (2008) Differential uptake for dioxin-like compounds by zucchini subspecies. Chemosphere 73 : 1602-1607

IPCS (2003) Polychlorinated biphenyls: human health aspects. Concise International Chemical Assessment Document (CICAD) No 55. World Health Organization/International Programme on Chemical Safety, Geneva

Liu J, Schnoor JL (2008) Uptake and translocation of lesser-chlorinated polychlorinated biphenyls (PCBs) in whole hybrid poplar plants after hydroponic exposure. Chemosphere 73:1608-1616

Liu M, Yang Y, Xu S, Liu H, Hou L, Ou D (2006) HCHs and DDTs in salt marsh plants (Scirpus) from the Yangtze estuary and nearby coastal areas, China. Chemosphere 62:440-448

Liu JY, Hu DF, Jiang GB, Schnoor JL (2009) In vivo biotransformation of 3,3',4,4'-tetrachlorobiphenyl by whole plants-poplars and switchgrass. Environ Sci Technol 43:7503-7509

Masters PM, Inman DL (2000) Transport and fate of organochlorines discharged to the salt marsh at upper Newport Bay California USA. Environ Toxicol Chem 19:2076-2084

Matsuo S, Yamazaki K, Gion K, Eun H, Inui H (2011) Structure-selective accumulation of polychlorinated biphenyls in Cucurbita pepo. $\mathrm{J}$ Pestic Sci 36:363-369

Meneses M, Schuhmacher M, Domingo JL (2002) A design of two simple models to predict $\mathrm{PCDD} / \mathrm{F}$ concentrations in vegetation and soils. Chemosphere 46:1393-1402

Mrozek E, Leidy RB (1981) Investigation of selective uptake of polychlorinated biphenyls by Spartina altemiflora Loisel. Bull Environ Contam Toxicol 27:481-488

Müller JF, Hülster A, Hülster A, Päpke O, Ball M, Marschner H (1994) Transfer of PCDD/PCDF from contaminated soils into carrots, lettuce, and peas. Chemosphere 29:2175-2181

Ryan PR, Delhaize E, Jones DL (2001) Function and mechanism of organic anion exudation from plant roots. Annu Rev Plant Physiol Plant Mol Biol 52:527-560

Satchivi NM, Stoller EW, Wax LM, Briskin DO (2001) A nonlinear dynamic simulation model of xenobiotic transport and whole plant allocation following foliar application. III. Influence of chemical properties, plant characteristics, and environmental parameters on xenobiotic absorption and translocation. Pestic Biochem Physiol 71: $77-87$

Schuhmacher M, Granero S, Rivera J, Muller L, Llobet JM, Domingo JL (2000) Atmospheric deposition of PCDD/Fs near an old municipal solid waste incinerator: levels in soil and vegetation. Chemosphere 40:593-600

Schuhmacher M, Jones KC, Domingo JL (2006) Air-vegetation transfer of PCDD/PCDFs: an assessment of field data and implications for modeling. Environ Pollut 142:143-150

Smith KEC, Jones KC (2000) Particles and vegetation: implications for the transfer of particle-bound organic contaminants to vegetation. Sci Total Environ 246:207-236 
Trapp S, Matthies M (1997) Modeling volatilization of PCDD/F from soil and uptake into vegetation. Environ Sci Technol 31:71-74

Uegaki R, Seike N, Otani T (2006) Polychlorinated dibenzo- $p$-dioxins, dibenzofurans, and dioxin-like polychlorinated biphenyls in rice plants: possible contaminated pathways. Chemosphere 65:15371543

Van den Berg M, Birnbaum L, Denison M, de Vito M, Farland W, Feeley M, Fiedler H, Hakansson H, Hanberg A, Haws L, Rose M, Safe S, Schrenk D, Tohyama C, Tritscher A, Tuomisto J, Tysklind M, Walker N, Peterson RE (2006) The 2005 World Health Organization reevaluation of human and mammalian toxic equivalency factors for dioxins and dioxin-like compounds. Toxicol Sci 93: 223-241

Wagrowski D, Hites R (1998) Partitioning of polychlorinated dibenzo- $p$ dioxins and dibenzofurans between the atmosphere and corn. Environ Sci Technol 32:2389-2393

Wall VD, Alberts JJ, Moore DJ, Newell SY, Pattanayek M, Pennings SC (2001) The effect of mercury and PCBs on organisms from lower trophic levels of a Georgia salt marsh. Arch Environ Contam Toxicol 40:10-17
Watts AW, Ballestero TP, Gardner KH (2006) Uptake of PAHs in salt marsh plants Spartina alterniflora grown in contaminated sediments. Chemosphere 62:1253-1260

Wenning RJ, Martello L, Prusak-Daniel A (2011) Dioxins, PCBs, and PBDEs in aquatic organisms. In: Beyer WN, Meador JP (eds) Environmental contaminants in Biota: Interpreting tissue concentrations. CRC Press, Boca Raton, pp 103-166

Wild E, Dent J, Thomas GO, Jones KC (2005) Direct observation of organic contaminant uptake, storage, and metabolism within plant root. Environ Sci Technol 39:3695-3702

Wu WZ, Schramm KW, Xu Y, Kettrup A (2002) Contamination and distribution of polychlorinated dibenzo- $p$-dioxins and dibenzofurans $(\mathrm{PCDD} / \mathrm{F})$ in agriculture fields in Ya-Er lake area, China. Ecotoxicol Environ Saf 53:141-147

Yeh M-F, Hong C-S (2002) Octanol-water partition coefficients of nonortho- and mono-ortho-substituted polychlorinated biphenyls. J Chem Eng Data 47:209-215

Zeeb BA, Amphlett JS, Rutter A, Reimer KJ (2006) Potential for phytoremediation of polychlorinated biphenyl - (PCB-) contaminated soil. Int J Phytoremediat 8:199-221 